\title{
Estimating the burden of food-borne illness in Canada
}

\author{
Thomas MK $^{1}$ and Murray $\mathbf{R}^{1}$ on behalf of \\ the Canadian Burden of Food-borne Illness Estimates Working Group* \\ 1 Public Health Agency of Canada, Centre for Food-borne, Environmental and Zoonotic Infectious Diseases, Ottawa, ON
}

* Correspondence to: enteric.surveillance.entérique@phac-aspc.gc.ca

\section{Abstract}

The Public Health Agency of Canada estimates that each year about 1 in 8 Canadians (4 million people) get sick from the food they eat. Four pathogens cause about $90 \%$ of the 1.6 million illnesses caused by known pathogens: Norovirus ( 1 million cases), Clostridium perfringens (177,000 cases), Campylobacter (145,000 cases) and nontyphoidal Salmonella (88,000 cases). These estimates are based on multiple complementary disease surveillance systems and the peer-reviewed literature. Understanding the burden of food-borne illness is useful for decision-makers, supporting the development of food safety and public health interventions, for research and for consumer education. Future efforts will focus on estimating the number of food-borne hospitalizations and deaths, the economic cost of food-borne illness and the burden of water-borne illness in order to provide crucial information to support research, policy and action.

\section{Introduction}

The Public Health Agency of Canada (the Agency) estimates that each year about 1 in 8 Canadians (4 million people) get sick from the food they eat (1). The results of a 2013 study show that four pathogens cause about $90 \%$ of the 1.6 million illnesses caused by known pathogens: Norovirus (1 million cases), Clostridium perfringens (177,000 cases), Campylobacter (145,000 cases) and nontyphoidal Salmonella (88,000 cases). This work represents collaboration between the Enteric Surveillance and Population Studies Division of the Centre for Foodborne, Environmental and Zoonotic Infectious Diseases and the Laboratory for Food-borne Zoonoses within the Agency. These estimates draw extensively from Canada's multiple complementary disease surveillance systems, which are crucial to the development of reliable estimates of the burden of food-borne illness as well as from peerreviewed literature. Such estimates are useful for decision-makers developing food safety interventions, public health professionals designing consumer education campaigns and, to inform future work, for researchers. This report will detail how these burden of illness estimates were calculated and describe future research plans to better inform efforts to reduce this considerable burden of illness to Canadians.

\section{How the estimates were calculated}

The Canadian burden of illness estimates are based extensively on data from four disease surveillance systems. The Canadian Notifiable Disease Surveillance System and the_National Enteric Surveillance Program provided data on laboratory-confirmed cases for select pathogens. The National Studies on Acute Gastrointestinal IIIness (NSAGI) includes population-based studies on the magnitude, distribution and burden of acute gastrointestinal illness (AGI) in Canada. Finally, FoodNet Canada is a sentinel site surveillance system that provides information on infectious gastrointestinal cases, clinical features, risk factors and sources of exposure. Table 1 gives a summary of the systems that contributed to the calculation of the burden of food-borne illness estimates. 
Table 1: Summary of Canadian surveillance databases used in the burden of food-borne illness estimates

\begin{tabular}{|c|c|c|c|}
\hline $\begin{array}{l}\text { Surveillance } \\
\text { database }\end{array}$ & Main functions & $\begin{array}{l}\text { Role in estimating the annual } \\
\text { burden of food-borne illness }\end{array}$ & Timeframe of data used \\
\hline $\begin{array}{l}\text { Canadian } \\
\text { Notifiable Disease } \\
\text { Surveillance } \\
\text { System (2) }\end{array}$ & $\begin{array}{l}\text { National database of laboratory- } \\
\text { confirmed illnesses for select } \\
\text { pathogens }\end{array}$ & $\begin{array}{l}\text { Provided total annual numbers } \\
\text { of laboratory-confirmed cases. }\end{array}$ & $2000-2008$ \\
\hline $\begin{array}{l}\text { National Enteric } \\
\text { Surveillance } \\
\text { Program (3) }\end{array}$ & $\begin{array}{l}\text { Aggregate counts of laboratory- } \\
\text { confirmed cases from provincial } \\
\text { laboratories for select pathogens }\end{array}$ & $\begin{array}{l}\text { Provided total annual numbers } \\
\text { of laboratory-confirmed cases. }\end{array}$ & $2000-2010$ \\
\hline $\begin{array}{l}\text { National Studies } \\
\text { on Acute } \\
\text { Gastrointestinal } \\
\text { Illness (4) }\end{array}$ & $\begin{array}{l}\text { Population studies explore the } \\
\text { magnitude, distribution and } \\
\text { burden of acute gastrointestinal } \\
\text { illness in Canada. }\end{array}$ & $\begin{array}{l}\text { Provided information on care- } \\
\text { seeking and stool submission } \\
\text { behaviour to inform under- } \\
\text { diagnosis multipliers. }\end{array}$ & $\begin{array}{l}\text { 2001-2002, 2002-2003 and } \\
2005-2006\end{array}$ \\
\hline FoodNet Canada (5) & $\begin{array}{l}\text { Sentinel site surveillance system } \\
\text { that provides information on both } \\
\text { cases of infectious } \\
\text { gastrointestinal illness and } \\
\text { sources of exposure within } \\
\text { defined communities. } \\
\text { Provides information on clinical } \\
\text { features and risk factors. }\end{array}$ & $\begin{array}{l}\text { Contributed information on } \\
\text { pathogen-specific severity of } \\
\text { symptoms (i.e. presence of } \\
\text { blood in diarrhea and the } \\
\text { duration of diarrhea) and travel- } \\
\text { related illnesses. }\end{array}$ & $2005-2010$ \\
\hline
\end{tabular}

Note: Though PulseNet Canada (6) and the Canadian Integrated Program for Antimicrobial Resistance Surveillance (7) were not used in developing these estimates they are other important surveillance systems for food-borne illness in Canada.

\section{Specified pathogens}

Estimates of the burden of food-borne illness are available for 30 specific pathogens. For some of these pathogens, such as Salmonella and Campylobacter, laboratory-confirmed cases are reported in our surveillance systems. For these pathogens the numbers of reported cases were adjusted for under-reporting and underdiagnosis. To do this, pathogen-specific multipliers were estimated to extrapolate the likely number of cases at the population level, by taking into account such factors as the probability that an affected individual will seek medical care and be tested, and the likelihood of a positive sample being reported to national surveillance. For example, for every case of Salmonella reported to national surveillance, it is estimated that there are about 26 cases occurring in the community. The complete parameters used to construct these multipliers can be found in the technical appendix accompanying the published report.

For other specified pathogens that are not adequately captured as part of Canadian laboratory-confirmed surveillance systems, such as norovirus or Clostridium perfringens, symptom-based models were applied to national data on the incidence of gastrointestinal illness to estimate the number of domestically acquired, foodborne cases occurring at the community level.

All of these initial estimates for specified pathogens were then further adjusted for the proportions that were likely to be travel-related and food-borne, in order to generate estimates of the annual burden of domestically acquired food-borne illnesses. For example, for Salmonella cases, $26 \%$ of illness is estimated to be travel-related, and $80 \%$ of domestic illness is estimated to be acquired through the food-borne route (as opposed to exposure through person-to-person contact, water, animals, etc.). 


\section{Unspecified agents}

Of the 4 million cases of food-borne illness, in only 1.6 million are the pathogens specified; the remaining 2.4 million are unspecified. These illnesses include those caused by known agents with insufficient data, undiscovered agents and unrecognized food-borne agents. To estimate the burden related to unspecified agents, data from the NSAGI population surveys were used to estimate the annual incidence of AGI in the Canadian population. The number of cases attributed to the 25 specified pathogens that are known to cause symptoms of AGI were subtracted from this national total ( 5 of the 30 known pathogens were excluded as they are not known to cause symptoms of AGI). The residual number of AGI cases was assumed to be caused by unspecified pathogens. This estimate was then adjusted for the proportions that were likely to be travel-related and foodborne, based on estimated proportions for the 25 known pathogens causing AGI.

\section{Discussion}

The knowledge that every year 4 million Canadians get sick from 30 food-borne pathogens (1.6 million) and unspecified agents (2.4 million) adds to the understanding of the burden of food-borne illness in Canada.

Estimates of this burden are important tools for planning and implementing programs to reduce such illnesses and can also help to inform consumer education campaigns as well as research.

The pathogen-specific findings from this study show a similar ranking of pathogens to those reported by international food-borne illness estimation efforts (United States $(8,9)$, the Netherlands (10), Australia (11), New Zealand (12) and France (13)), though each country has employed slightly different methods based on different available data sources. For example, in the United States it is estimated that the same four major pathogens (Norovirus, Clostridium perfringens, Campylobacter, nontyphoidal Salmonella spp.) cause approximately $88 \%$ of food-borne illnesses (8). The similarity of the results validates the accuracy of the current Canadian estimates.

Future work related to this initiative being led by the Agency includes generating estimates for the annual number of hospitalizations and deaths related to food-borne illness, and estimating the economic costs to Canada of the illnesses associated with these same 30 pathogens and unspecified agents. In addition, the Agency is leading efforts to estimate the burden of water-borne illness and is currently implementing an expert elicitation process to further inform our understanding of the dominant routes of transmission for key enteric pathogens in Canada.

\section{Conclusion}

Canada is fortunate to have a large supply of valuable surveillance and population study data to support burden of illness initiatives. This is only possible with broad collaboration among the provinces and territories across Canada. The estimates of the burden of food-borne illness provide crucial information to support research, policy and action. Future work will help to further our understanding of food-borne illness and interventions to prevent it.

\section{Acknowledgements}

The authors wish to acknowledge the support of the Enteric Surveillance and Population Studies Division, Centre for Food-borne, Environmental, and Zoonotic Infectious Diseases, Public Health Agency of Canada: Nadia Ciampa, Danielle Dumoulin, Rita Finley, Logan Flockhart, Elizabeth Hillyer, Matt Hurst, Lisa Landry, Barbara Marshall, Laura Martin, Pia Muchaal, Andrea Nesbitt, Stephen Parker, Katarina Pintar, Frank Pollari and Kate Thomas. We also thank Rachael Vriezen for assistance in preparing this manuscript.

\section{Conflict of Interest}

No conflicts of interest to declare. 


\section{References}

(1) Thomas MK, Murray R, Flockhart L, Pintar K, Pollari F, Fazil A, et al. Estimates of the burden of foodborne illness in Canada for 30 specified pathogens and unspecified agents, circa 2006. Foodborne Pathog Dis 2013;10(7):639-48.

(2) Notifiable Diseases On-Line. http://dsol-smed.phac-aspc.gc.ca/dsol-smed/ndis/index-eng.php

(3) National Enteric Surveillance Program (NESP). https://www.nml-Inm.gc.ca/NESP-PNSME/index-eng.htm

(4) National Studies on Acute Gastrointestinal Illness (NSAGI). http://www.phac-aspc.gc.ca/nsagi-enmga/pop-eng.php

(5) FoodNet Canada (formerly known as C-EnterNet). http://www.phac-aspc.gc.ca/foodnetcanada/index-eng.php

(6) PulseNet Canada. https://www.nml-Inm.gc.ca/Pulsenet/index-eng.htm

(7) Canadian Integrated Program for Antimicrobial Resistance Surveillance (CIPARS). http://www.phacaspc.gc.ca/cipars-picra/index-eng.php

(8) Scallan E, Hoekstra RM, Angulo FJ, Tauxe RV, Widdowson MA, Roy SL, et al. Foodborne illness acquired in the United States - major pathogens. Emerg Infect Dis 2011 Jan;17(1):7-15.

(9) Scallan E, Griffin PM, Angulo FJ, Tauxe RV, Hoekstra RM. Foodborne illness acquired in the United States - unspecified agents. Emerg Infect Dis 2011 Jan;17(1):16-22.

(10) Havelaar AH, Haagsma JA, Mangen MJ, Kemmeren JM, Verhoef LP, Vijgen SM, et al. Disease burden of foodborne pathogens in the Netherlands, 2009. Int J Food Microbiol 2012 Jun 1;156(3):231-8.

(11) Hall G, Kirk MD, Becker N, Gregory JE, Unicomb L, Millard G, et al. Estimating foodborne gastroenteritis, Australia. Emerg Infect Dis 2005 Aug;11(8):1257-64.

(12) Cressey P, Lake R. Estimated incidence of foodborne illness in New Zealand: application of overseas models and multipliers. MPI Technical Paper. New Zealand: New Zealand Government; 2011. Report No.: 2012/11.

(13) Vaillant V, de Valk H, Baron E, Ancelle T, Colin P, Delmas MC, et al. Foodborne infections in France. Foodborne Pathog Dis 2005 Fall;2(3):221-32. 